\title{
TORTS, CONTRACTS, PROPERTY, STATUS, CHARACTER- IZATION, AND THE CONFLICT OF LAWS
}

FOWLER V. HARPER*

This is a formidable title, involving areas where angels fear to tread. Nevertheless, some of us are foolish enough to rush in. A few years ago Dean Prosser, for example, somehow got himself tangled up in a conflict of laws problem involving torts. "[C]onflict of laws," he said, "is a dismal swamp, filled with quaking quagmires, and inhabited by learned but eccentric professors who theorize about mysterious matters in a strange and incomprehensible jargon."1 After pushing the problem around the swamp for sixty pages, he came to the startling conclusion that "something will have to be done about all this."2

It is doubtful that this conclusion is sound. It is true that there are many knotty problems here. It is also true that the law of conflict of laws is a complicated apparatus difficult if not impossible to reduce to satisfactory black letter and one that requires considerable skill to manipulate. At the same time, in the hands of a competent judge, it is, perhaps more than most branches of law, eapable of meeting the requirements of justice. Let us look at some of the possibilities.

To begin at the beginning, conflict of laws rules are formulated in terms of categories or classifications of law, on the one hand, and of connecting factors or "contact points," on the other. Right here we have a difficulty, and it is not trivial. There is a whole literature on the subject. ${ }^{3}$ This article is intended as no more than a footnote to that literature as it relates to problems in torts.

Every science begins with classification. But law is only somewhat scientific. A lawyer need not be very sophisticated to realize that the administration of law is as much an art as a science. Law reflects a way of life. Even after von Jhering, it is not trite to refer to it as a means to an end. The "ends" have little to do with science. Nor do we need the authority of Holmes

* Simeon E. Baldwin Professor of Law, Yale University.

1. Prosser, Selected Topics on the Law of Torts 89 (1953).

2. $I d$. at 133 .

3. E.g., Cook, The Logical and Legal Bases of Conflict of Laws (1942); DICEY, CONFLICT OF LAWS 41-63 (7th ed. 1958); FALCONBRIDGE, EsSAYS ON THE CONFLICT OF LAWS (2d ed. 1954); RoBerTSON, Characterization IN THE CoNFLICT OF LAws (1940); Cormack, Renvoi, Characterization, Localization, and Preliminary Question in the Conflict of Laws, 14 So. CAL. L. Rev. 221 (1941); Freund, Characterization With Respect to Contracts in the Conflict of Lares, in LECTURES ON THE CONFLICT OF LAWS AND INTERNATTONAI CoNTRACTS 158 (1951); Lorenzen, The Qualification, Classification, or Characterization Problem in the Conflict of Laws, 50 YAt. L. J. 743 (1941); Morse, Characterization: Shadow or Substance, 49 CoLum. L. REv. 1027 (1949). 
to recognize that the life of the law is not logic. Holmes notwithstanding, it is not exclusively experience either, except in the broadest connotation of that word, and even then we must include the hopes and aspirations of the community against the backdrop of its customs, mores, traditions, and superstitions. Nevertheless, most of the world, and particularly our part of it, is committed to striving for order in law in order to bring order in life. Thus we have legal classifications. But the lines are dim, and there is much gray between the black and the white. Where do "torts" end and "contracts" begin? Where do we pass from "property" law into "tort" law? Where is the line that separates the law of "torts" from the law of "administration of decedent's estates"? It is a problem of classification; in the "incomprehensible jargon" of conflict of laws, "characterization." We have similar problems in identifying the contact points-“domicile," "nationality," "the place of wrong," "place of contracting," and even "situs."

Suppose, for example, an action is brought in state $A$ for breach of a promise to marry which was made in state $B$ by a citizen of $B$ and broken in state $C$ by his marriage there to a female domiciliary of $A$. The man has an excuse for not fulfilling his promise under $B$ law but not under $C$ or $A$ law. Under the $A$ conflict of laws rules, the validity of a contract and excuses for nonperformance are governed by the law of the place where the contract was made $(B)$; tort law is governed by the place of wrong $(C)$. Under $A$ and $C$ law, the breach of a promise to marry involves liability for breach of contract, but under $B$ law it involves tort liability. If the question is regarded as one of contract law, $B$ law will control and defendant will not be liable. ${ }^{*}$ If it is treated as a matter of tort law, $C$ law will govern and he probably will be liable, notwithstanding that under $C$ law it is not characterized as a tort. The preliminary question is: By what law will the characterization be made? The question, of course, must be answered by the court of the forum. ${ }^{5}$

Again, let us consider a Missouri case $^{\mathfrak{b}}$ which was brought under the Oklahoma wrongful death statute because the injury was received in Oklahoma. A provision of the Oklahoma constitution required that the question of contributory negligence be decided by the jury. In Missouri the judge had the power to direct a verdict on this question. Under Oklahoma decisions that state's constitutional provision concerned a matter of procedure, ${ }^{7}$ but

4. This assumes that the court in $A$ will not refer to the "whole law" of the foreign state. Cf. University of Chicago v. Dater, 277 Mich. 658, 270 N.W. 175 (1936).

5. See Dicex, Conflict of Laws 43 (7th ed. 1958).

6. Hopkins v. Kurn, 351 Mo. 41, 171 S.W.2d 625 (1943).

7. It should be pointed out that the Oklahoma case, Independent Cotton Oil Co. v. Beacham, 31 Okla. 384, 120 Pac. 969 (1911), on which the Missouri court primarily relied in holding that it was dealing with a procedural rule, involved the retroactive application of a constitutional provision. The Oklahoma court had upheld the application of the provision on the ground that no one had a vested right in a rule of procedure. 
Missouri characterized such provisions as matters of substantive law. Under the Missouri and Oklahoma conflict of laws rules, all matters of procedure were governed by the law of the forum. The court employed the Oklahoma characterization and held that the Missouri law on the direction of a verdict was controlling. If the court had followed the characterization of the Missouri law, the Oklahoma rule would have applied.

There are various solutions offered for these problems, ${ }^{8}$ but about the only thing that can be said with confidence on the subject is that the law is probably unsettled in all jurisdictions. Perhaps one sensible approach is that the forum should follow its own characterization with one or two exceptions. ${ }^{2}$ The basis for this solution is obvious. Whatever policy has prompted the forum to adopt a particular choice of law rule would be distorted if the characterization of some foreign law were adopted. For example, if the law of the forum provides that the law of the place of wrong governs liability in tort but some other law determines what is the place of wrong, the forum policy in selecting the place of wrong as the governing law may be subverted. Similarly, if the forum rules are that the place of wrong governs tort liability but the place of making a contract determines contract liability, the fortum loses control over the situation if a foreign law determines whether the case is one of tort or contract liability. In the Missouri-Oklahoma case set forth above, the Missouri (forum) rule that its courts follow local procedure is subverted if the Oklahoma law dictates what law is procedure and what is substance. ${ }^{10}$

A similar problem exists where there is a difference in the characterization or delimitation of the connecting factors. The law of states $A$ and $B$ might be identical in that the place where a contract is made governs its validity and interpretation. But in the case of an offer from $B$ to an office

Regardless of the desirability of the result in the Missouri case, it seems clear that the court fell into error in assuming without discussion that the word "procedure" has the same meaning in all contexts. See Cook, "Substance" and "Procedure" in the Conflict of Laws, 42 YALE L.J. 333 (1933).

The Massachusetts court fell into the same error in Levy v. Steiger, 233 Mass. 600 , 124 N.E. 477 (1919), which involved the question whether the Massachusetts statute placing the burden of proof on the defendant in a negligence case should be applied when the accident occurred in Rhode Island. The court held it applicable as a rule of procedure, relying on a previous case which involved the constitutionality of an application of the statute. It well may be that the distinction between "substance" and "procedure" should be drawn at different places when it serves different purposes.

8. See DiCEY, CoNflict of Laws 45-52 (7th ed. 1958).

9. The usual exceptions are: (1) the situs of tangible things determines whether the law will deal with them as movable or immovable property; and (2) if two potentially applicable laws characterize an issue in the same way, that characterization will be accepted although it differs from that of the forum. See Robertson, op. cit. supra note 3 , at $75-78$.

10. According to the usage of some writers, this is a problem of secondary characterization. The initial or primary characterization was made before any reference could be made to the substantive law of Oklahoma. 
in $A$ by correspondence and an acceptance mailed in $A$, different results will be obtained if under $A$ law the contract is "made" in $A$ where the acceptance was dispatched and under $B$ law it is made in $B$ where the acceptance was received. ${ }^{11}$ Here again, whether the forum is $A$ or $B$, the policy of the local law is defeated if the foreign characterization of the connecting factor is followed.

When it comes to choice of law, the most popular rule for torts is that the law of the "place of wrong" governs questions of substantive law. But where is the "place of wrong"? It is said in the Restatement and in a number of cases that the place of wrong is the place where the last act or event necessary to liability for an alleged tort takes place. ${ }^{12}$ But this a rubric, not one of the Ten Commandments.

In the easiest of eases, the "place of wrong" rule is probably about as good as any other. If a man injures another in India, the average person in the western world is quite likely to believe that he should not be brought to term in England, Connecticut, or New York by any law other than that of India. Of course, there is the "public policy" principle,13 but since India is a nation at least as civilized as our own, there should seldom be a serious problem here. When we are faced with a multi-state tort, however, the difficulty increases.

Suppose that a cow is raised in Texas and shipped to Chicago where it is slaughtered and packed. The meat is sent by the packing company to all the states in the United States, England, and India. The meat is not edible and has not been subjected to the statutory processing and testing required by the state of Illinois. A housewife in Connecticut, England, or India (a Muslim) buys a part of this animal, becomes ill as a result of the contamination, and brings an action against the packing company. Where is the "place of wrong"? According to the rubric, it is where the "last act or event" occurred. This would be in Connecticut, England, or India, where we will assume there are no statutory requirements similar to those of Illinois.

11. Compare In re Missouri S.S. Co., 42 Ch. D. 321 (C.A. 1889), with Liverpool \& Great W. Steam Co. v. Phenix Ins. Co., 129 U.S. 397 (1889).

12. Restatement, Conflict of Laws $\$ 377$ (1934). Alabama G. So. R.R. v. Carroll, 97 Ala. 126, 11 So. 803 (1892), is the leading case. Others are cited in GoodRICH, CoNFLICT OF LAwS 263 (3d ed. 1949), where an attempt is made to justify the rule on analytical grounds. "The plaintiff does not sue the defendant for the latter's negligence, but because the negligence has caused the plaintiff harm." Ibid. But this does not make very good sense, for it could as well be said that the plaintiff does not sue the defendant because the latter eaused the plaintiff harm but because he negligently caused harm. In such cases, both factors are essential to the cause of action.

13. This refers to the rationale which allows the forum to decline to apply the otherwise applicable law under its choice of law rule because its application would offend a deep-scated public policy of the forum. See Loucks v. Standard Oil Co., 224 N.Y. 99, 120 N.E. 198 (1918); Goodrich, Public Policy in the Laze of Conflicts, 36 W. VA. I.Q. 156 (1930) ; Paulsen \& Sovern, "Public Policy" in the Conflict of Laws, 56 Colum. L. Rev. 969 (1956). 
It would offend almost anyone's sense of justice if the packing company could escape liability merely because the plaintiff lives in Connecticut, England, or India, rather than Illinois. ${ }^{14}$ Although some literal-minded courts have failed to find liability, it has not overtaxed the imagination of others to find that the "place of wrong" was the place where the tortious behavior occurred, rather than the place where the plaintiff sustained harm.. ${ }^{15}$

In the case of harm to persons or physical things, it is usually not too difficult to identify the place where the last act or event necessary to liability occurred. But in the case of harm to relational interests or intangible things, it becomes more complicated. A case involving alienation of affections is illustrative of the difficulties. A young naval officer and his wife are domiciled in Pennsylvania. When he is ordered abroad, she moves to Boston and gets a job in a navy yard. In Massachusetts she falls in love with another officer, divorces her husband, and remarries. On his return the ex-husband sues his successful rival in a federal court in Massachusetts. Such an action is barred by Pennsylvania, which has a "hcart balm" statute. The common law prevails in Massachusetts. Where was the "place of wrong"? In a sense the plaintiff "lost" his wife's affections in Massachusetts where she fell in love with the defendant. It may plausibly be argued, however, that his "loss" of consortium was in his domicile (which was also the "matrimonial domicile"), Pennsylvania. ${ }^{16}$

The fraud cases also present difficulties. A case in a federal court in New Jersey, Smyth Sales v. Petroleum Heat \& Power Co., ${ }^{17}$ may be regarded as typical. Plaintiff entered into a contract with defendant pursuant to which he acquired the exclusive right to sell defendant's fuel oil in a certain county in New Jersey. Several years later he sold his business to defendant by a contract which recited all moneys purportedly due between the parties. The

14. An even more absurd result could conceivably be brought about if Connecticut had legislation similar to that of Illimois, but in a case before it the Connecticut court would decline to apply the Illinois statutes on the ground that they were applicable only when the injury was sustained in Illinois (the "place of wrong") and would not invoke the Connecticut statutes because they were applicable only to meat processed in Connecticut.

15. In Schmidt v. Driscoll Hotel, Inc., 249 Minn. 376, 82 N.W.2d 365 (1957), the court held the Minnesota Dram Shop Act applicable in a case where liquor was sold to an intoxicated person in Minnesota, but the automobile accident in which plaintiff sustained injury was in Wisconsin. Compare Levy v. Daniels U-Drive Auto Renting Co., 108 Conn. 333, 143 Atl. 163 (1928), in which a Connecticut statute imposing vicarious liability upon the bailor-for-hire of an automobile was applied to an out-ofstate accident because the transaction of bailment had taken place in Connecticut.

16. See Gordon v. Parker, 83 F. Supp. 40 (D. Mass. 1949), where Massachusetts law was applied. If the case is considered on a policy basis, it may be asked which state's law should apply on the grounds of state "interest." Pennsylvania certainly has an interest in the rights of Pennsylvania spouses against third persons who interfere with their domestic relations. On the other hand, Massachusetts has a legitimate concern with the extent to which a single man in Massachusetts may be permitted to compete with a husband for the affections of his wife.

17. 128 F.2d 697 (3d Cir. 1942) (Goodrich, J.). 
agreement was consummated at the defendant's home office in Connecticut. Shortly thereafter plaintiff discovered that defendant had permitted another company to sell its products in plaintiff's territory while the agreement was in effect. Plaintiff sued for the commissions paid the other party, alleging fraudulent misrepresentation in the closing sale. It was held that under the rule of Erie R.R. v. Tompkins ${ }^{18}$ the federal court in New Jersey must apply the New Jersey conflict of laws rule and that that rule in tort actions was that the law of the place of wrong governs. It was further held that the place of wrong in cases of fraud and deceit is the place where the loss was sustained. ${ }^{10}$ The court then said:

The alleged loss here is the sale of plaintiff's business for an inadequate consideration, settlement for commissions at a sum substantially less than actually due and the damage resulting therefrom. Since the event which occasioned these losses was the execution of the contract of sale in Connecticut, reference must be made to the law of Connecticut to determine whether the plaintiff has established the substantive elements of its claimed cause of action for deceit. ${ }^{20}$

But it would seem that although Connecticut was the place where the fraudulent representations were made, ${ }^{21}$ the loss of plaintiff's business and commissions was in New Jersey, his business territory.

In cases involving contractual transactions, there is still more elasticity.22 To be sure, again some courts are rigid, following the "place of making" or "place of performance" rule. For the most part, however, it is the "proper" law which is applied. And what is the "proper" law? In England, almost invariably, it is the law intended or presumed to have been intended by the parties. $^{23}$ Of course, the "presumed intention" is frequently pure fiction. American courts are apt to find the proper law (although they do not use the term) to be the law of the state or country which has the most significant contacts-the center of gravity of the transaction. ${ }^{24}$

In dealing with property interests in tangible things, the law of the physical situs is the customary rule in Anglo-American conflict of laws. ${ }^{25}$

18. 304 U.S. 64 (1938).

19. Citing Restatement, Conflict of Laws $\$ 377$ note pt. 4 (1934), 2 Beale CoNFLTCT OF LAWS $\$ 377.2$ (1935), and several cases.

20. 128 F.2d at 699 .

21. The Restatement provision cited in the opinion, $\S 377$, is as follows: "When a person sustains loss by fraud, the place of wrong is where the loss is sustained, not where fraudulent representations are made." (Emphasis added.)

22. See Ehrenzweig, The Real Estate Broker and the Conflict of Laws, 59 Colum. L. REv. 303 (1959).

23. See DICEY, CONFLICT OF Laws 717-38 (7th ed. 1958)

24. E.g., W. H. Barber Co. v. Hughes, 223 Ind. 570, 63 N.E.2d 417 (1945); Auten v. Auten, 308 N.Y. 155, 124 N.E.2d 99 (1954).

25. Thomson v. Kyle, 39 Fla. 582, 23 So. 12 (1897) ; Cammell v. Sewell, 5 Hurl. \& N. 728, 157 Eng. Rep. 1371 (Ex. 1860); Restatenent, Conflict of Laws \$211 (1934). 
Intangibles, such as debts, insofar as they are dealt with as "property," must necessarily be treated differently, although formerly the fiction of situs was often employed.

Initially, then, a court faced with a conflict of laws case must identify or characterize it as to the proper legal eategory; otherwise it will not know which choice of law rule to apply. It cannot refer to the appropriate law unless it knows what kind of a problem it has on its hands. So indistinct are the lines of demarcation that frequently a court may have several plausible choices.

Judge Learned Hand took advantage of the availability of several alternatives in the following case. ${ }^{26}$ While insolvent, a bankrupt had entered into contracts in New York to transfer real and personal property in Missouri, Florida, and New Jersey to four of its creditors. The transfers were made accordingly. Since the property was not recoverable as a preference under the bankruptcy act, the trustee sought relief under a New York statute which made preferential transfers of this character invalid. It was conceded that the transfers were or might be valid under the laws of Missouri, Florida, and New Jersey. One could expect the court to apply the law of the situs. Not so, however. The court rendered a personal decree against the transferees ordering them to convey the property to the trustee. It characterized the problem as tort or contract, probably the former. Judge Hand reasoned:

Although the bill does not say where the transfers were made, the contracts required them to be delivered in [New York] . . and we are to assume that the parties performed as stipulated. The receipt of the deeds by the defendants was therefore a wrong, and any liability imposed as a remedy would be recognized and enforced elsewhere, for the law of the place where acts occur normally fixes their jural character. ... The question here is whether it makes a difference that the wrong consisted in the conveyance of property in another state, under whose laws the conveyance might perhaps have been valid. It is in general no obiection to a lialitity arising out of a consensual transaction that it may be determined by events happening in another jurisdiction.27

The second italicized sentence sounds more like contract, the first more like tort. However, in a later part of the opinion, he apparently returns to the tort idea: "The law of New York might still make receipt of the deed a wrong and impose a liability upon the grantee though he got a good title." ${ }^{28}$ And near the end he declares that "the validity of the conveyance depends on the lex rei sitae, but any court may compel the tortfeasor specifically to restore the property, whatever the law of the situs." 29

26. Irving Trust Co. v. Maryland Cas. Co., 83 F.2d 168 (2d Cir. 1936).

27. Id. at 171. (Emphasis added.)

28. Ibid.

29. Id. at 172 . 
Regardless of the double talk, it is obvious that the court felt that the interests of justice required the transferees to yield their preferences for equitable distribution. Characterization of the problem as one of tort made such a decision possible.

The automobile industry has left a long trail in the conflict of laws, ever since the courts held that a bona fide purchaser of a horse mortgaged in another state took a title superior to that of the mortgagee. ${ }^{30}$ Horse and buggy lien law has given way in the conflict of laws to what we call progress. ${ }^{31}$ A Michigan case ${ }^{32}$ is typical: An action for conversion of an automobile was brought by a New York mortgagee against a Detroit dealer who had bought the vehicle from the mortgagor. The mortgage had been properly recorded in New York but not in Michigan. Overruling a prior (horse) case, the court held that the mortgagee should be protected at the expense of the innocent buryer. This is now the usual rule in the United States. ${ }^{33}$

In most of these cases the courts do not discuss the conflict of laws rules relating to torts. Usually the language is in terms of "property," "security," or "situs." In Federman v. Verni, ${ }^{34}$ however, the court made the usual tort analysis. The plaintiff had bought a truck in Philadelphia from a mortgagor. Both mortgagor and mortgagee were New York residents and the mortgage had been executed there. The defendant mortgagee repossessed the truck on default by the mortgagor. Under the law of New York the mortgagee was protected, but under Pennsylvania law the bona fide purchaser for value was protected. The federal court in New York held that (1) the action was for conversion; (2) the New York choice of law rule was that the law of the place where the wrongdoer's conduct occurs determines liability; $(3)$ the conversion took place in Pennsylvania; and (4) Pennsylvania law controlled and the plaintiff recovered.

Now consider the Rogers case in the federal district court for Minnesota. ${ }^{35}$ The federal government loaned money and received a chattel mortgage on certain cattle located in Wisconsin. Thereafter the mortgagor delivered the animals to a livestock commission merchant in Minnesota, who sold them in the usual course of his trade. The Government sued the commission agent for conversion. The court examined the law of conversion in both Minnesota and Wisconsin and found that under Minnesota law such a sale was a conversion but that under Wisconsin law it was not. If the court had followed

30. See, e.g., Allison v. Teeters, 176 Mich. 216, 142 N.W. 340 (1913).

31. See Leary, Horse and Buggy Lien Law and Migratory Automobiles, 96 U. PA. L. REv. 455 (1948).

32. Metro-Plan, Inc. v. Kotcher-Turner, Inc., 296 Mich. 400, 296 N.W. 304 (1941).

33. See Restatement, Conflict of Laws §268 (1934); Leary, supra note 31.

34. 42 F. Supp. 113 (E.D.N.Y. 1941).

35. United States v. Rogers \& Rogers, 36 F. Supp. 79 (D. Minn. 1941). 
the rule of the "place of wrong," it would have applied Minnesota law. It was there that the defendant exercised "dominion" over the chattels by selling and delivering them to the buyer. But the court did not apply Minnesota law. It reasoned as follows:

The action is in tort. It is argued by the government that the conversion took place in the State of Minnesota. The general rule is that the creation and extent of tort liability is governed by the law of the place where the tort was committed, that the action is transitory and may be brought wherever the wrongdoer may be found and jurisdiction obtained, but the law of the place where the right was acquired or the liability incurred will control as to the right of action. ...

The right of the plaintiff to maintain this action for conversion must depend necessarily upon the rights granted to him under the law of Wisconsin. The chattel mortgage given on property in Wisconsin is the foundation of those rights. . . .

The gist of an action in conversion is a wrongful assumption of dominion and control over property. The law of Wisconsin is that neither a sale by the mortgagor of property subject to a chattel mortgage, nor a subsequent sale by his vendee constitutes a conversion of the property described in the chattel mortgage. ... .

It is my opinion that the question of the right of the mortgagee to maintain this action in conversion goes to the substantive rights of the parties. Determination of this question involves an interpretation of the rights, which plaintiff here claims were violated, and which were created under the chattel mortgage. We must be guided by the interpretation of those rights of the plaintiff under this Wisconsin chattel mortgage by the decisions of the State of Wisconsin, which, under the circumstances we have in this case, say that no rights of a chattel mortgage contract have been violated. ${ }^{30}$

At first reading this appears to be confused reasoning, and the language indeed sounds odd. The court states that the action is one for conversion, but it later finds for the defendant because "no rights of a chattel mortgage contract have been violated." The average lawyer may momentarily be puzzled when told that the question whether a conversion has been committed depends on whether there has been a breach of contract. On second thought, however, he will remember that in a number of instances such is the case. Misdelivery by a carrier, ${ }^{37}$ unlawful disposition by a bailee, ${ }^{38}$ and improper use of a chattel by a bailee ${ }^{39}$ are common examples. What makes the Rogers

36. $I d$. at $80-81$.

37. Restatement, Torts $\$ 234$.(1934). Dean Prosser has assembled a large number of situations in which there is no tort unless there is a breach of contract. Prosser, op. cit. silpra note 1 , at $402-52$.

38. RESTATEMENT, TORTS $\$ 232$ (1934),

39. Id. §228. 
case appear unusual is the application of this type of analysis in characterizing a problem for conflict of laws purposes.

It could be argued, as no doubt counsel for the Government did argue, that this is a simple case of conflict of laws involving torts. The chattel alleged to bave been converted was in Minnesota at the time, the defendant's acts were done in Minnesota, and as a result the plaintiff was deprived of its property. Surely the place of wrong was Minnesota. From another point of view, since Minnesota was the situs of the chattel at the time of the acts in question, it would appear that under conflict of laws principles Minnesota law sbould determine whether the acts were or were not sufficient to deprive the plaintiff of his property rights and vest title in another.

But the court's decision, although perhaps not all of its language, can be explained to make good sense. It may well be that the court did not adequately state the law of Minnesota. It is true that the Minnesota cases held that it was a conversion to sell mortgaged chattels without the consent of the mortgagee and without the vendee's knowledge of the lien. But the broader principle of Minnesota law no doubt is that dealing with a chattel in such a manner as to deprive another of his property interests therein is a conversion. It is necessary, therefore, to determine just what those property interests are. Whatever property the mortgagee had in the chattels was acquired in Wisconsin, which was the situs of the chattels and the place of the transaction, i.e., the conveyance. The Wisconsin conveyance created in the mortgagee certain rights, powers, privileges, and immunities-a whole "bundle" of them-with respect to this chattel, vis à vis both the mortgagor and the rest of the world under Wisconsin law, which appears by all odds to be the "proper" law of the contract and the situs of the chattel at the time. Simultaneously, it destroyed an equivalent "bundle" in the mortgagor. The problem is whether the transaction created in the mortgagee a right which is violated if a bona fide bailee or vendee of the mortgagor sells the chattel to a bona fide purcbaser? When the case is analyzed as a conveyancing or property problem, it is not difficult to arrive at the conclusion that the Wisconsin law should be controlling.

Two New Jersey cases present a nice study in characterization and the confusion which can result if the problem is not understood. In the first, the Marvin case, ${ }^{40}$ a Pennsylvanian sold a safe in Pennsylvania to a resident of New Jersey, retaining title in himself as security for the balance of the purchase price. The buyer subsequently sold the safe to a bona fide purchaser in New Jersey. The conditional seller then sued the second purchaser in New Jersey for conversion. Under the local Pennsylvania law a bona fide

40. Marvin Safe Co. v. Norton, 48 N.J.L. 410, 7 At1. 418 (Sup. Ct. 1886). 
purchaser prevailed over a conditional seller in such circumstances. The New Jersey law was otherwise-the purchaser from a conditional vendee acquired only such rights and title as his vendor had. New Jersey law was applied.

In the second, the Krimke case, ${ }^{41}$ plaintiff delivered a diamond ring to a jewelry broker in New York for examination. The broker took the ring to New Jersey and sold it to the defendant, who paid value with no knowledge or notice of the broker's want of title. Under the New York Factor's Act, a bona fide purchaser under the conditions of this case prevailed over the owner. Under New Jersey law, the owner prevailed. The New Jersey court applied New York law, and defendant kept the ring.

In Krimke, the court thought it was following the principle of the Marvin case. Under the New York transaction, the broker acquired a certain aggregate of rights, powers, privileges, and immunities. One of the powers was to convey a good title to a good faith purchaser. This, according to the decision, enabled him to convey such a title in New Jersey. In other words, this power accompanied him and the ring into New Jersey. "He had control of the title, under the law of the state of New York, as did plaintiff in the Marvin Case, under the Pennsylvania law."42

If this argument is stated fast enough, it carries an overtone of plausibility. But on second thought, something is wrong. In the Marvin case, as in the Krimke case, the person in possession of the chattel when it was sold to the bona fide purchaser had the power to endow defendant with a complete property interest under the law of the state of the first transaction but not under the New Jersey law. What the court in Krimke apparently did not realize was that it was giving effect in New Jersey to the powers acquired by the bailee under New York law, whereas in Marvin the court confined to Pennsylvania the exercise of the conditional vendee's power acquired under Pennsylvania law to invest a bona fide purchaser with a good title.

Here again, an oversimplified characterization of the problem could result in the following syllogism. Defendant's liability in each case depends on whether he has converted plaintiff's property. Conversion is a tort. The lex loci delicti determines whether a tort has been committed. The alleged conversion occurred in New Jersey. New Jersey law applies. The result obtained in the Marvin case is consistent with this analysis. The Krimke case is not.

A more sophisticated approach would call for an inquiry into the nature and extent of the plaintiff's "property" which he alleges has been "converted."

41. Charles E. Dougherty Co. v. Krimke, 105 N.J.L. 470, 144 Atl. 617 (Ct. Err. \& App. 1929).

42. Id. at 474, 144 Atl. at 618. 
It is to be observed that in the Marvin case, the conditional vendor was in a better position and received greater protection than if the safe had been sold to a good faith purchaser in Pennsylvania. Under the result of that case, the conditional vendor's "property rights" magically incrcased when the safe crossed the state line into New Jersey. Thus, the defendant committed a tort by buying the safe in New Jersey, whereas if it had been a Pennsylvania transaction before the safe had been taken out of the state, his purchase would not have been tortious. The alternative analysis calls for a double characterization, viz., splitting the problem into its "tort" aspect, on the one hand, and its "property" or "contract" aspect, on the other, and applying the appropriate conflict of laws rule to each.

When the action is between the original parties to the transaction, even though the action is for conversion the contract characterization may be indicated so clearly that most courts could be expected not to miss it. In Thomas G. Jezett, Inc. v. Keystone Driller Co., ${ }^{43}$ a gasoline shovel which had been sold under a conditional sale contract in Massachusetts but which had been delivered to the buyer in New Hampshire was repossessed by the seller in New Hampshire on the buyer's default and resold in Connecticut. The conditional buyer sued the seller in Massachusetts alleging that the seller had committed a conversion by the Connecticut sale. Under Massachusetts law the buyer's right of redemption terminated fifteen days after repossession, but under New Hampshire law notice of sale was required and no such notice had been given. The court made no mention of Connecticut law. The case was dealt with solely as a conflict of laws case involving contracts. The court held that it was a Massachusetts contract, since it was made in that state, and that, accordingly, New Hampshire law was inapplicable.

There was a dissenting opinion which took the position that New Hampshire law should have been applied because the shovel was delivered to the plaintiff in New Hampshire, which was thus the situs when the plaintiff's rights were acquired. It seems clear that the dissenting judge, in relying upon situs as the contact point, was characterizing the situation as one involving primarily the law of property.

There are, of course, several lines of cases in which an action either in tort or in contract is allowed. If they involve a conflict of laws problem, the characterization may be vital. In a Kentucky case, ${ }^{44}$ plaintiff bought a railroad ticket in Louisville for Atlantic City and return. He was injured in an accident in Pennsylvania. In a New York case, ${ }^{45}$ plaintiff had bought

43. 282 Mass. 469,185 N.E. 369 (1933).

44. Pittsburgh, C., C., \& St. L. Ry. v. Grom, 142 Ky.-51, 133 S.W. 977 (1911). See also Prosser, op. cit. supra note 1 , at 422 .

45. Dyke v. Erie Ry., 45 N.Y. 113 (1871): See also Boulevard Airport, 'Inc. v. Consolidated Vultee Aircraft Corp., 85 F. Supp. 876 (E.D. Pa. 1949); Conklin v. Cana- 
a ticket in Buffalo to New York City. He too was injured in an accident in Pennsylvania. The Kentucky court characterized the problem as tort and applied Pennsylvania law. The New York court characterized it as contract and applied New York law. Of course in both cases there was both a breach of contract and a tort (assuming negligence on the part of the carrier). Formerly the form of action or the characterization adopted by the pleader might have been controlling. Under modern procedure, it would seem to be immaterial which label the plaintiff has put on his case so long as he has stated facts which constitute some kind of a cause of action under the proper law. The careful and knowledgcable lawyer will analyze his case and the competing laws which could be applicable and characterize his case accordingly.

Sometimes it is difficult to distinguish between the label or tag applied to a transaction and the characterization of its substance. This is brought out ncatly in two conversion cases. One involved the validity of a Michigan transaction in an Illinois forum. ${ }^{46}$ The defendant argued that the contract was invalid because it was unrecorded. Under Michigan law it was a chattel mortgage, but under Illinois law it was a conditional sale. The court disposed of the problem with the following language:

In this case the contract specifically provides that the law of Michigan shall be applicable. Under Michigan law, although the instrument is held to be a chattel mortgage, recording is not necessary. On the other hand, if we regard the law of Illinois as applicable, the agreement is one for a conditional sale which by the law of Illinois need not be recorded. Therefore, whether we regard the law of Michigan or of Illinois as applicable, and whether we regard the agreement as a chattel mortgage in Michigan or a conditional sales agreement in Illinois, it was unnecessary that the agreement be recorded. There is no statute in Illinois requiring an instrument to be recorded in this state solely because under Michigan law it would be denominated a chattel mortgage. The character of the instrument rather than the name given it would seem to be determinative. ${ }^{47}$

In a federal case, ${ }^{48}$ the respective states were reversed: an Illinois contract of sale and a Michigan forum. Under the law of Illinois it was a conditional sale, but under Michigan law it was a chattel mortgage. Again the issue was one of recording. The court rcasoned:

dian-Colonial Airways, 266 N.Y. 244, 194 N.E. 692 (1935) ; Rauton v. Pullman Co., 183 S.C. 495 , 191 S.E. 416 (1937); Gilliland \& Gaffney v. Southern Ry., 85 S.C. 26, 67 S.E. 20 (1910). (1938).

46. Ford Motor Co. v. National Bond \& Inv. Co., 294 I1l. App. 585, 14 N.E.2d 306

47. Id. at 596, 14 N.E.2d at 311.

48. Enterprise Optical Mfg. Co. v. Timmer, 71 F.2d 295 (6th Cir. 1934). 
The fallacy in the appellant's contention is that it confuses the label with the goods, and nomenclature with substance. Michigan does not require the recording of conditional sale contracts, but its courts do not include within the definition of conditional sales contracts those in which two cumulative and inconsistent remedies ... are reserved. The claimant's contention is that, because the Illinois courts designate agreements such as are here involved conditional sales contracts, it necessarily follows that the contract is such in Michigan-clearly a non sequitur. ${ }^{49}$

Strange conflicts eapers are sometimes performed by the courts in order to achieve a result which conforms to their conception of justice in the case before them. An English case ${ }^{50}$ is illustrative. An action was brought against the English executrix of a deceased Austrian who had possessed an estate in Austrian lands similar to a common law estate tail. It was claimed and admitted that certain waste had been committed by the decedent. There was no doubt about defendant's liability under Austrian law, but the action was in an English court, and the question arose whether the action sounded in tort or in contract. Defendant claimed that it was a tort action analogous to waste, which, according to English law, died with the person. It was held that the acts of waste were not to be regarded as torts but as breaches of an obligation in the nature of an implied contract, and the claim was allowed.

In a Louisiana ease, ${ }^{51}$ the court solved the problem in a manner satisfactory to itself by ignoring the characterization problem altogether. A natural shallow drain traversed plaintiff's Arkansas land, extending into defendant's adjoining Louisiana land. Both parties were residents of Louisiana. Defendant constructed a dam across the drain on his land, thus impounding water on plaintiff's land. Under Arkansas law defendant had a right to prevent the flow onto his land. Under Louisiana law he had no such right. The action could have been characterized as a nuisance or trespass under the usual principles, or it could well have been characterized as a problem of property law. In either case legal orthodoxy would have suggested Arkansas law. The court apparently thought that one Louisiana citizen ought not to do this to another, even in Arkansas. It held the defendant liable under Louisiana law.

What a fertile-minded judge can do with the characterization tool is nowhere better demonstrated than in the performance of Justice Traynor in handling a tort ease before the Supreme Court of California. ${ }^{52}$ The char-

49. Id. at $296-97$.

50. Batthyany v. Walford, 36 Ch. D. 269 (1887).

51. Caldwell v. Gore, 175 La. 501, 143 So. 387 (1932).

52. Emery v. Emery, 45 Cal. 2d 421, $289^{2}$ P.2d 218 (1955), discussed in Kelso, Antomobile Accidents and Indiana Confict of Laws: Current Dilemmas, 33 IND. L.J. 297, 305-10 (1958); cf. Koplik v. C. P. Trucking Corp., 47 N.J. Super. 196, 198-99, 135 
acterization problem appears occasionally in connection with choice of law rules pertaining to contracts and status, but seldom in connection with rules governing torts and status. Justice Traynor, however, was able to bring it about deftly. In that case, a suit by minor children against their father, all of whom apparently were California domiciliaries, was brought in California for a personal tort committed in Idaho. California law allowed such claims, but Idaho did not. The classical disposition of this case would be to look to Idaho law-the place of wrong under any theory-and dismiss the case. Not so, however, under the Traynor opinion, which represented the unanimous view of the court. The court declared that the problem was not one of tort but one of the capacity of a child to sue his parent. This is a matter of the law of status and such matters are, under orthodox conflict of laws rules, referred to the law of the domicle, although the law of the forum is sometimes applied.

The same court, the same judge writing the opinion, held in Grant v. $M c A_{\text {uliffe }}^{53}$ that California law applied to determine whether a cause of action for injuries received in an Arizona automobile accident survived the death of the alleged tort-feasor. The cases on this point had been divided, some holding that the question of survival was a matter of substantive law governed by the place of wrong, others regarding it as procedural and controlled by the law of the forum.

Justice Traynor's position is not clear. At one point he seems to adopt the procedural characterization. But it also appears that he regards the question as one of the administration of the decedent's estate:

Decedent's estate is located in this state, and letters of administration were issued to defendant by the courts of this state. The responsibilities of defendant, as administrator of Pullen's estate, for injuries inflicted by Pullen before his death are governed by the laws of this state. ... Today, tort liabilities of the sort involved in these actions are regarded as compensatory. When, as in the present case, all the parties were residents of this state, and the estate of the deceased tort feasor is being administered in this state, plaintiffs' right to prosecute their causes of action is governed by the laws of this state relating to administration of estates. ${ }^{54}$

And at another point he says that "the problem here is whether the causes of action that these plaintiffs had against Pullen before his dcath survive as liabilities of his estate."

A 2d 555, 556-57 (Super. Ct. 1957) (dictum); Cheatham \& Reese, Choice of the Appl:cable Law, 52 Colum. L. Rev. 959, 975 (1952); Morris, The Proper Law of a Tort, 64 HARv. L. REv. 881, 885-86 (1951).

53. 41 Cal. 2d 859, 264 P.2d 944 (1953), discussed in Kelso, supra note 52, at 317-19.

54. $41 \mathrm{Cal}$. $2 \mathrm{~d}$ at 867,264 P.2d at 949 .

55. Id. at 866,264 P.2d at 949. 
Related to the problem of characterization but distinct. from it is the so-called incidental question. This arises in a situation where the solution of the main conflict of laws problem incidentally involves another and subsidiary conflicts problem. Will the forum apply its own conflict of laws rule to the subsidiary issue, or will it apply the conflicts rule of the state to which the main or original question is referred? There are two schools of thought but not much authority. ${ }^{56}$

The following hypothetical wrongful death case presents this situation. An injury resulting in death was sustained in Illinois where decedent and his family were domiciled at the time. An action is brought in Minnesota under the Illinois wrongful death statute. The question is raised by the defendant whether the plaintiff is actually the widow of the decedent, since they were first cousins, forbidden to marry under the law of Illinois. It is claimed by plaintiff that the marriage was valid because the ceremony was performed in Kentucky where marriage between first cousins is valid. Under Minnesota conflict of laws rules, a marriage valid where performed is valid in Minnesota, with exceptions which do not affect marriage between first cousins. Under Illinois law the Uniform Marriage Evasion Act is in force; it provides that marriages between residents of the state who go through the ceremony in another state in order to avoid Illinois law are void.

Will the Minnesota court apply its own conflict of laws rule relating to the validity of marriages, or will it apply the confiicts rule of the place of wrong (Illinois) to which it referred the main question? In Meisenhelder $v$. Chicago \& N.W. Ry, ${ }^{57}$ the Minnesota court applied the conflicts rule of the place of wrong. That action was brought under the Federal Employers Liability Act, however, and the decision therefore is not dispositive of the hypothetical case.

It is quite possible to have a situation in which the incidental question is still further removed in space and sequence. In the above action for wrongful death in Minnesota, suppose the doubt as to the validity of the Kentucky marriage of the Illinois domiciliaries arises not because they were cousins but because the decedent had had a former wife from whom he had obtained a divorce in Mexico while he was a resident of Illinois. Neither Illinois nor Minnesota recognizes Mexican divorces, but let us assume that Kentucky does. The favored principle with most American conflict of laws writers is to refer all such problems to the law of the domicile of the parties, and probably a court would do the same and apply the law of Illinois, thus

56. See Dicey, Conflict of Laws 57-63 (7th ed. 1958).

57. 170 Minn. 317,213 N.W. 32 (1927).

58. See Restatement, Conflict of Laws $\$ 132$ (1934); Goodrich, Conflict of LAws 348 (3d ed. 1949). 
denying the woman's status under the wrongful death statute. Here, Illinois was hoth the domicile and the place of wrong. If this Illinois decedent had been killed in Ohio, however, a good argument could be made that the Minnesota court should apply Ohio law to determine whether the woman is a widow. Presumably, when the Ohio law designated the "widow" as a beneficiary under the wrongful death statute, "widow" had the meaning as understood in the law of Ohio-not in the law of Illinois, Kentucky, Minnesota, or Mexico.

To end at the beginning, many problems in the conflict of laws raise delicate and complicated questions in the borderland between torts, on the one hand, and contracts, property, status, and other branches of the law, on the other. This, of course, creates a degree of uncertainty, but at the same time it lends a compensatory flexibility to the law, gives the courts a plausible choice of alternatives through the medium of characterization, and thus, it is submitted, affords an instrument of value for the administration of justice. 